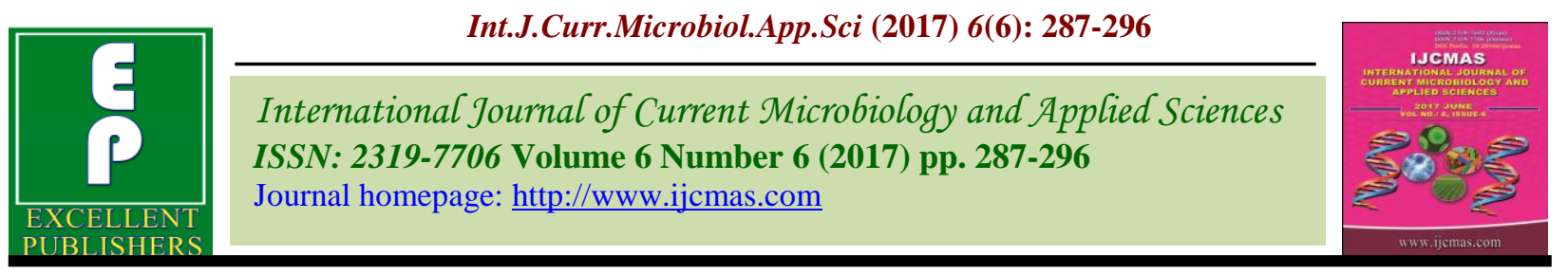

Original Research Article

https://doi.org/10.20546/ijcmas.2017.606.035

\title{
Effect of Integrated Nutrient Management on Physico-Chemical Characters of Bael (Aegle marmelos Correa) cv. Narendra Bael-9
}

\author{
Govind Vishwakarma ${ }^{1 *}$, A.L. Yadav, Amit Kumar, Amar Singh ${ }^{2}$ and Sonu Kumar ${ }^{3}$ \\ ${ }^{1}$ Department of Horticulture, Narendra Deva University Agriculture and Technology, \\ Kumarganj Faizabad - 224 229, U.P., India \\ ${ }^{2}$ Department of Horticulture, Chandra Shekhar Azad University Agriculture and Technology, \\ Kanpur - 208002, U.P., India \\ ${ }^{3}$ Department of Horticulture, Chaudhary Charan Singh Haryana Agricultural University, \\ Hisar - 125004, Haryana, India \\ *Corresponding author
}

\begin{tabular}{|c|c|}
\hline \multirow[b]{3}{*}{ Keywords } & A B S T R A C T \\
\hline & \multirow{10}{*}{$\begin{array}{l}\text { The present investigation was carried out at Main Experiment Station, } \\
\text { Horticulture, Narendra Deva University of Agriculture and Technology, } \\
\text { Kumarganj Faizabad (U.P.) under sodic soil condition during the years 2014-15 } \\
\text { and 2015-16 to evaluate the response of organic manure, inorganic fertilizer and } \\
\text { bio-fertilizer on physic-chemical characters of bael fruit cv. Narendra Bael-9. The } \\
\text { experiment was laid out with treatments viz. T1-100\% NPK, T2-50 Kg FYM, T3- } \\
50 \mathrm{Kg} \text { FYM + 100\% NPK, T4-50 Kg FYM + 75\% NPK, T5-50 Kg FYM + 50\% } \\
\mathrm{NPK}, \mathrm{T} 6-50 \mathrm{Kg} \text { FYM + 200g each (Azotobacter + PSB), T7-50 Kg FYM + 100\% } \\
\mathrm{NPK}+200 \mathrm{~g} \text { each (Azotobacter + PSB), T8-50 Kg FYM + 75\% NPK + 200g each } \\
\text { (Azotobacter + PSB) and T9-50 Kg FYM + 50\% NPK + 200g each (Azotobacter } \\
+ \text { PSB) and replicated four times with Randomized Block Design. The physico- } \\
\text { chemical characters were found significantly superior over all other treatments } \\
\text { while physical characters like specific gravity, number of cavity/fruit and shell } \\
\text { thickness (mm) were found non-significant during both the years of } \\
\text { experimentation (2014-15 and 2015-16) respectively. }\end{array}$} \\
\hline & \\
\hline Organic manures, & \\
\hline Inorganic & \\
\hline fertilizer, & \\
\hline Bio-fertilizers, & \\
\hline FYM, NPK, Bael. & \\
\hline Article Info & \\
\hline $\begin{array}{l}\text { Accepted: } \\
\text { 04 May } 2017 \\
\text { Available Online: } \\
\text { 10 June } 2017\end{array}$ & \\
\hline & \\
\hline
\end{tabular}

\section{Introduction}

The bael (Aegle marmelos Correa) is an important fruit of India, which belongs to family Rutaceae. It has been known in India from prehistoric times and has a great mythological significance. It is regarded as sacred tree for Hindus, because worship of Lord Shiva's cannot be accomplished without its leaves. The bael has been frequently mentioned in Ramayana, Yajurveda, Buddhist and Jain literature. It is known with different names in different languages; Bel, Beli, Belgiri (Hindi), Shivadruma, Shivapahala, Vilva (Sanskrit), Bael, (Assamese and Marathi), Bilvaphal (Gujrati), Marredy (Malayam), Belo (Oriya), Vilvom, Vilvamarum (Tamil) and Bilvapandu (Telgu). Every part of plant such as fruit, seed, bark, leaf, flower and root has important ingredients 
of several traditional formulations. The twigs and leaves are used as fodders, sweet scented water is distilled from the flower, and leaf juice is applied to body before taking a bath to remove the bad smell. The most valuable part of the tree is fruit due to its curative properties. It is one of the most useful medicinal plants of India from pre-historic time and has been essential in the ancient system of medicinal "Ayurveda". The bael fruit is highly nutritious. Physico-chemical studies have revealed that bael fruit is rich in mineral and vitamin contents like Vitamin $\mathrm{A}$, $\mathrm{B}, \mathrm{C}$ and high content of carbohydrates. The ripe fruit is a tonic as restorative, laxative and good for heart and brain problems. No other fruits have such a high content of Riboflavin, Marmelosin $\left(\mathrm{C}_{14} \mathrm{H}_{12} \mathrm{O}_{4} \neg\right)$ is most probably the therapeutically activity principle of bael fruits. Bael seedling (Deshi) tree takes 7-8 years to commence in bearing while budded plants start bearing from fourth year after planting. It grows throughout the Indian peninsular as well as in Sri Lanka, Pakistan, Bangladesh, Burma, Thailand and most of the south east Asian countries, the tree are found in the wild states in Utter Pradesh, Orissa, Bihar, West Bengal, Madhya Pradesh etc., However, data on area and productivity per unit area and suitability under various kinds of wasteland situation, the cultivation of this fruit is being popular day by day. It is being cultivated in limited areas is Gonda, Basti, Deoria, Mirzapur and Etawah districts of Utter Pradesh and several districts of Bihar, Madhya Pradesh and Rajasthan. It is a very hardy subtropical, deciduous tree that can thrive well in various soil-climates conditions and can tolerate alkaline soil and is injured by temperature as low as $7^{\circ} \mathrm{C}$ and $\mathrm{pH}$ up to 9 . Bael is deciduous and hardy in nature, which can thrive well in salt affected soil up to 30 ESP and $9 \mathrm{dSm}^{-1}$.

The continuous applications of huge amount of chemical fertilizers hamper the fruit quality, soil health and generate pollution. The integrated nutrient management paves a way to overcome these problems. Plant nutrient can be supplied from different sources viz., organic manures, crop residues, bio-fertilizers and chemical fertilizers for better utilization of resources and to produce crop with less expenditure, INM is the best approach for sustainable crop production. In this approach all the possible sources of nutrients are applied, based on economic consideration. Organic manures enhance nutrient availability in order to improve the soil health, soil structure and provide environment is conducive for the treatment of soil micro-flora. Potentially of using organic manures along with balanced fertilizers are well established in increasing crop yield and sustained crop production (Nambiar and Abrol, 1992). The importance of integrated nutrient supply system which involves the combined use of various plant nutrient sources has now assured significance in the field of fruit production. The conjugation use of bio-fertilizers with nitrogenous fertilizers increases the efficiency of nitrogen, improve the soil health and control the soil pollution. It is therefore, necessary to standardize other possible sources of nutrients to a specific soil and agro-climate condition for better plant growth, production and quality of fruits.

\section{Materials and Methods}

The field experiment was carried out at Main Experimental Station and P.G. Laboratory, Department of Horticulture, Narendra Deva University of Agriculture and Technology, Kumarganj, Faizabad (U.P.) during the years 2014-15 and 2015-16. The 20 years old plants of the bael cultivars Narendra Bael-9 having uniform vigour were selected randomly. The experiment was laid out with nine treatments viz. T1-100\% NPK, T2-50 Kg FYM, T3-50 $\mathrm{Kg}$ FYM + 100\% NPK, T4-50 Kg FYM + 75\% NPK, T5-50 Kg FYM + 50\% NPK, T6- 
$50 \mathrm{Kg} \mathrm{FYM} \mathrm{+} \mathrm{200g} \mathrm{each} \mathrm{(Azotobacter} \mathrm{+}$ PSB), T7-50 Kg FYM + 100\% NPK + 200g each (Azotobacter + PSB), T8-50 Kg FYM + $75 \% \mathrm{NPK}+200 \mathrm{~g}$ each (Azotobacter $+\mathrm{PSB})$ T9-50 Kg FYM + 50\% NPK +200g each (Azotobacter+ PSB) and replication four in Randomized Block Design. The experiment was conducted under sodic soil condition to evaluate the response of organic manure, inorganic fertilizer and bio-fertilizer on physical characters like fruit length $(\mathrm{cm})$, fruit width $(\mathrm{cm})$, fruit weight (kg/fruit), pulp weight ( $\mathrm{kg} /$ fruit), number of seed/fruit, shell weight ( $\mathrm{g} / \mathrm{fruit}$ ), specific gravity, number of cavity/fruit, shell thickness (mm) and chemical characters like Total Soluble Solids (TSS)(0Brix), Ascorbic acid (mg/ 100gpulp), Acidity (\%), Tannin (\%), Reducing sugars $(\%)$, Non-reducing sugar (\%), Total sugars $(\%)$ and Total carotene $(\mu \mathrm{g} / 100 \mathrm{~g}$ pulp)of bael fruit.

\section{Results and Discussion}

\section{Physical characters}

It is evident from table 1 that the soil application of organic manure inorganic and bio-fertilizer recorded the significantly superior results in all treatments during both the years of experimentation (2014-15 and 2015-16) respectively. The significantly maximum $(24.00 \mathrm{~cm}$ and $24.62 \mathrm{~cm})$ fruit length was recorded with the use of T7-50 Kg FYM $+100 \% \mathrm{NPK}+200 \mathrm{~g}$ each (Azotobacter + PSB) followed with the soil application of T8$50 \mathrm{Kg} \mathrm{FYM} \mathrm{+} \mathrm{75 \%} \mathrm{NPK} \mathrm{+} \mathrm{200g} \mathrm{each}$ (Azotobacter + PSB). The treatment consist $50 \mathrm{~kg}$ FYM was showed lowest $(17.30 \mathrm{~cm}$ and $17.46 \mathrm{~cm})$ fruit length as compare to others treatments during both the years of experimentation. Whereas the data recorded for fruit width was found significantly maximum $(18.08 \mathrm{~cm}$ and $19.32 \mathrm{~cm})$ with the use of $50 \mathrm{Kg}$ FYM + 100\% NPK + 200g each (Azotobacter + PSB) which was found at par with the spoil application of T8-50 Kg FYM $+75 \% \mathrm{NPK}+200 \mathrm{~g}$ each (Azotobacter + PSB) and T3-50 Kg FYM + 100\% NPK followed with the use of T9-50 Kg FYM + $50 \% \mathrm{NPK}+200 \mathrm{~g}$ each (Azotobacter+ PSB) during both the year and minimum $(15.43 \mathrm{~cm}$ and $15.69 \mathrm{~cm}$ ) fruit width was recorded with the use of 50kg FYM during both the years of experimentation (2014-15 and 2015-16) respectively. It seems from the data that the maximum $(2.41 \mathrm{~kg} /$ fruit and $2.45 \mathrm{~kg} /$ fruit $)$ fruit weight was recorded with the use of $50 \mathrm{Kg}$ FYM $+100 \%$ NPK $+200 \mathrm{~g}$ each (Azotobacter + PSB) which was found at par with the use of $50 \mathrm{Kg}$ FYM $+75 \% \mathrm{NPK}+200 \mathrm{~g}$ each (Azotobacter + PSB) and T3-50 Kg FYM + $100 \%$ NPK followed with the treatment of T9-50 Kg FYM + 50\% NPK +200g each (Azotobacter+ PSB) and application $50 \mathrm{~kg}$ FYM was recorded minimum $(2.10 \mathrm{~kg} /$ fruit and $2.13 \mathrm{~kg} /$ fruit) fruit weight as compare to all others treatments during both the years of experimentation (2014-15 and 2015-16) respectively. However specific gravity was found non-significant during both the years of experimentation.

The increase in fruit size (length and width) and fruit weight are due to the optimum supply of plant nutrients in right amount during entire crop period caused more plant height and ultimately more photosynthesis that resulted to more length and breadth of fruit (Govindan and Purushothamam, 1984; Atiyeh, 2002). Mani et al., (2013) reported maximum increase in length and diameter of phalsa fruits with the application of Azotobacter inoculated treatment with $75 \% \mathrm{~N}$ substitution by phosphate solubilizing bacteria and remaining $25 \%$ through inorganic fertilizer in two equal splits at establishment and before flowering stage. Singh et al., (2013) recorded maximum fruit size with treatment when phosphorus was applied 50\% through bone meal+50\% $\mathrm{P}$ through FYM and remaining $\mathrm{N}$ and $\mathrm{K}$ through 
urea and muriate of potash followed by others treatments.

Data showed in table 2, for pulp weight of fruit was found maximum $(2.10 \mathrm{~kg}$ and $2.14 \mathrm{~kg}$ ) with the use of $50 \mathrm{Kg}$ FYM $+100 \%$ $\mathrm{NPK}+200 \mathrm{~g}$ each (Azotobacter + PSB) which was found at par with the use of $50 \mathrm{Kg}$ FYM $+75 \% \mathrm{NPK}+200 \mathrm{~g}$ each (Azotobacter + PSB) and T3-50 Kg FYM + 100\% NPK followed with the treatment of $\mathrm{T} 9-50 \mathrm{Kg}$ FYM + 50\% NPK +200g each (Azotobacter+ PSB)while the treatment comprised $50 \mathrm{Kg}$ FYM shows lowest $(1.67 \mathrm{~kg}$ and $1.70 \mathrm{~kg}$ ) pulp weight than other treatments during both the years of experimentation. The number of seed per fruit was found significantly maximum (114.50 and 120.75) with the use of $50 \mathrm{Kg}$ FYM $+100 \%$ NPK $+200 \mathrm{~g}$ each (Azotobacter + PSB) which was found at par with the use of $50 \mathrm{Kg}$ FYM + 75\% NPK + 200g each $($ Azotobacter + PSB) followed with the soil application of T3-50 Kg FYM + 100\% NPK while number of cavity per fruit was recorded non-significant during both the years of experimentation. The lowest $(80.75$ and 82.25) number of seeds per fruit was recorded with the use of $50 \mathrm{Kg}$ FYM because fruit was less in weight (Table 3 ). It is evident from the data presented in table 4, shows that the minimum (303.44g and 306.50g) shell weight was recorded with the use of $50 \mathrm{Kg} \mathrm{FYM}+$ $100 \% \mathrm{NPK}+200 \mathrm{~g}$ each (Azotobacter $+\mathrm{PSB})$ which was found at par with the use of $50 \mathrm{Kg}$ $\mathrm{FYM}+75 \% \mathrm{NPK}+200 \mathrm{~g}$ each (Azotobacter + PSB) (2014-15), T3-50 Kg FYM + 100\%, T9-50 Kg FYM + 50\% NPK +200g each (Azotobacter+ PSB) and T4-50 kg FYM+ $75 \%$ NPK during the year 2015-16 while shell thickness was found non-significant during both the years of experimentation. The treatment used with 50Kg FYM was noted maximum $(426.94 \mathrm{~g}$ and $430.00 \mathrm{~g}$ ) shell weight during both the years.
The increase in pulp weight, number of seed/fruit and Shell weight might be due to the fact that Azotobacter enhances the rate of cell division and multiplication to better over all food and nutrient status of plants under this treatment. The combination of PSB in this treatment increased the availability of phosphorus and subsequent uptake by the plants due to phosphate solubilizers might also have improved vigour of berries since phosphorus is known to improve the quality of fruits. The results are close conformity with the finding of Aariff (2004) in the acid lime by the soil application of iron pyrites [pyrites] (IP at 100, 200 and $300 \mathrm{~g} /$ plant), press mud (PM at 4 and $8 \mathrm{~kg} /$ plant), farmyard manure (FYM at 25 and $50 \mathrm{~kg} /$ plant) and VAM (150 g/plant), either individually or in combination, in both years. Kumar et al., (2012), Ghosh et al., (2012), Manjunath et al., (2006) and Bendegumbal et al., (2008) were also found same results by the application of organic and inorganic manures on different fruit crops.

\section{Chemical characters}

The data recorded on chemical characters like Total Soluble Solids (TSS), Ascorbic acid and Total carotene were significantly improved by the soil application of FYM+ NPK with biofertilizers (Azotobacter and PSB). The maximum TSS (35.66 0Brix and 37.85 0Brix), Ascorbic acid (20.75mg/ 100gpulp and $21.26 \mathrm{mg} / 100 \mathrm{gpulp}$ ) and Total carotene $(55.84 \mu \mathrm{g} / 100 \mathrm{~g}$ pulp and $55.72 \mu \mathrm{g} / 100 \mathrm{~g}$ pulp) were recorded with the use of T7-50 Kg FYM $+100 \% \mathrm{NPK}+200 \mathrm{~g}$ each (Azotobacter + PSB) followed by $\mathrm{T} 8-50 \mathrm{Kg}$ FYM $+75 \%$ $\mathrm{NPK}+200 \mathrm{~g}$ each (Azotobacter + PSB) over all others treatments while the treatments T250kg FYM keeps lowest results during both the years (2014-15 and 2015-16) of experimentation. 
Table.1 Showing the effect of INM on physical characters of Bael cv. NB-9

\begin{tabular}{|c|c|c|c|c|}
\hline \multirow[t]{2}{*}{ Treatment } & \multicolumn{2}{|c|}{ Fruit length $(\mathrm{cm})$} & \multicolumn{2}{|c|}{ Fruit width $(\mathrm{cm})$} \\
\hline & 2014-15 & $2015-16$ & 2014-15 & 2015-16 \\
\hline $\mathrm{T}_{1}: 100 \% \mathrm{NPK}$ & 17.10 & 17.58 & 15.93 & 16.00 \\
\hline $\mathrm{T}_{2}: 50 \mathrm{~kg} \mathrm{FYM}$ & 17.30 & 17.46 & 15.43 & 15.69 \\
\hline $\mathrm{T}_{3}: 50 \mathrm{~kg}$ FYM+ $100 \% \mathrm{NPK}$ & 20.95 & 22.34 & 17.43 & 17.97 \\
\hline $\mathrm{T}_{4}: 50 \mathrm{~kg}$ FYM+ $75 \% \mathrm{NPK}$ & 18.93 & 18.98 & 16.40 & 16.91 \\
\hline $\mathrm{T}_{5}: 50 \mathrm{~kg} \mathrm{FYM}+50 \% \mathrm{NPK}$ & 17.53 & 17.97 & 16.23 & 16.32 \\
\hline $\mathrm{T}_{6}: 50 \mathrm{~kg}$ FYM+ 200g each (Azotobacter+PSB) & 17.85 & 18.35 & 16.85 & 16.61 \\
\hline $\mathrm{T}_{7}: 50 \mathrm{~kg}$ FYM+ $100 \% \mathrm{NPK}+200 \mathrm{~g}$ each $($ Azotobacter $+\mathrm{PSB})$ & 24.00 & 24.62 & 18.08 & 19.32 \\
\hline $\mathrm{T}_{8}: 50 \mathrm{~kg}$ FYM+ 75\% NPK+200g each (Azotobacter+PSB) & 22.38 & 23.64 & 17.65 & 18.53 \\
\hline $\mathrm{T}_{9}: 50 \mathrm{~kg}$ FYM+ 50\% NPK+200g each (Azotobacter+PSB) & 20.03 & 21.78 & 17.10 & 17.22 \\
\hline S. Em \pm & $\mathbf{0 . 5 3}$ & 0.68 & 0.08 & 0.56 \\
\hline CD at $5 \%$ & 1.55 & 1.99 & $\mathbf{0 . 2 3}$ & 1.65 \\
\hline
\end{tabular}

Table.2 Showing the effect of INM on physical characters of Bael cv. NB-9

\begin{tabular}{|c|c|c|c|c|c|c|}
\hline \multirow[t]{2}{*}{ Treatment } & \multicolumn{2}{|c|}{ Fruit weight (kg) } & \multicolumn{2}{|c|}{ Specific gravity } & \multicolumn{2}{|c|}{ Pulp weight (kg) } \\
\hline & 2014-15 & $2015-16$ & 2014-15 & $2015-16$ & 2014-15 & $2015-16$ \\
\hline $\mathrm{T}_{1}: 100 \% \mathrm{NPK}$ & 2.17 & 2.19 & 0.975 & 0.975 & 1.77 & 1.80 \\
\hline $\mathrm{T}_{2}: 50 \mathrm{~kg} \mathrm{FYM}$ & 2.10 & 2.13 & 0.971 & 0.975 & 1.67 & 1.70 \\
\hline $\mathrm{T}_{3}: 50 \mathrm{~kg} \mathrm{FYM}+100 \% \mathrm{NPK}$ & 2.34 & 2.36 & 0.978 & 0.978 & 2.01 & 2.04 \\
\hline $\mathrm{T}_{4}: 50 \mathrm{~kg} F Y M+75 \% \mathrm{NPK}$ & 2.29 & 2.31 & 0.975 & 0.968 & 1.94 & 1.97 \\
\hline $\mathrm{T}_{5}: 50 \mathrm{~kg} \mathrm{FYM}+50 \% \mathrm{NPK}$ & 2.22 & 2.25 & 0.976 & 0.974 & 1.85 & 1.88 \\
\hline $\mathrm{T}_{6}: 50 \mathrm{~kg}$ FYM+ 200g each (Azotobacter+PSB) & 2.26 & 2.28 & 0.975 & 0.970 & 1.91 & 1.93 \\
\hline $\mathrm{T}_{7}: 50 \mathrm{~kg} \mathrm{FYM}+100 \% \mathrm{NPK}+200 \mathrm{~g}$ each (Azotobacter+PSB) & 2.41 & 2.45 & 0.976 & 0.975 & 2.10 & 2.14 \\
\hline $\mathrm{T}_{8}: 50 \mathrm{~kg}$ FYM+ 75\% NPK+200g each (Azotobacter+PSB) & 2.36 & 2.42 & 0.975 & 0.976 & 2.04 & 2.10 \\
\hline $\mathrm{T}_{9}: 50 \mathrm{~kg} \mathrm{FYM}+50 \% \mathrm{NPK}+200 \mathrm{~g}$ each $($ Azotobacter $+\mathrm{PSB})$ & 2.30 & 2.33 & 0.977 & 0.972 & 1.96 & 1.99 \\
\hline S. Em \pm & 0.02 & $\mathbf{0 . 0 3}$ & 0.002 & 0.002 & $\mathbf{0 . 0 3}$ & 0.03 \\
\hline CD at $5 \%$ & 0.08 & 0.11 & NS & NS & 0.10 & 0.11 \\
\hline
\end{tabular}


Table.3 Showing the effect of INM on physical characters of Bael cv. NB-9

\begin{tabular}{|l|c|c|c|c|}
\hline \multirow{2}{*}{ Treatment } & \multicolumn{2}{c|}{ No. of seed/fruit } & \multicolumn{2}{c|}{ No. of cavity/fruit } \\
\cline { 2 - 5 } & $\mathbf{2 0 1 4 - 1 5}$ & $\mathbf{2 0 1 5 - 1 6}$ & $\mathbf{2 0 1 4 - 1 5}$ & $\mathbf{2 0 1 5 - 1 6}$ \\
\hline $\mathrm{T}_{1}: 100 \% \mathrm{NPK}$ & 89.00 & 94.75 & 11.50 & 11.50 \\
\hline $\mathrm{T}_{2}: 50 \mathrm{~kg}$ FYM & 80.75 & 82.25 & 11.00 & 11.00 \\
\hline $\mathrm{T}_{3}: 50 \mathrm{~kg}$ FYM+ 100\% NPK & 100.50 & 110.75 & 13.00 & 13.00 \\
\hline $\mathrm{T}_{4}: 50 \mathrm{~kg}$ FYM+ 75\% NPK & 93.75 & 99.00 & 12.50 & 12.50 \\
\hline $\mathrm{T}_{5}: 50 \mathrm{~kg}$ FYM+ 50\% NPK & 90.00 & 95.75 & 12.25 & 12.00 \\
\hline $\mathrm{T}_{6}: 50 \mathrm{~kg}$ FYM+200g each (Azotobacter+PSB) & 91.50 & 97.25 & 12.00 & 12.00 \\
\hline $\mathrm{T}_{7}: 50 \mathrm{~kg}$ FYM+ 100\% NPK+200g each (Azotobacter+PSB) & 114.50 & 120.75 & 13.50 & 13.75 \\
\hline $\mathrm{T}_{8}: 50 \mathrm{~kg}$ FYM+ 75\% NPK+200g each (Azotobacter+PSB) & 111.00 & 116.50 & 13.25 & 13.00 \\
\hline $\mathrm{T}_{9}: 50 \mathrm{~kg}$ FYM+ 50\% NPK+200g each (Azotobacter+PSB) & 105.75 & 111.75 & 12.75 & 12.75 \\
\hline S. $\mathbf{E m} \pm$ & $\mathbf{1 . 6 7}$ & $\mathbf{2 . 1 8}$ & $\mathbf{0 . 6 1}$ & $\mathbf{0 . 6 0}$ \\
\hline CD at 5\% & $\mathbf{4 . 8 9}$ & $\mathbf{6 . 3 7}$ & $\mathbf{N S}$ & $\mathbf{N S}$ \\
\hline
\end{tabular}

Table.4 Showing the effect of INM on physical characters of Bael cv. NB-9

\begin{tabular}{|l|c|c|c|c|}
\hline \multirow{2}{*}{ Treatment } & \multicolumn{2}{c|}{ Shell weight $(\mathbf{g})$} & \multicolumn{2}{c|}{ Shell thickness (mm) } \\
\cline { 2 - 5 } & $\mathbf{2 0 1 4 - 1 5}$ & $\mathbf{2 0 1 5 - 1 6}$ & $\mathbf{2 0 1 4 - 1 5}$ & $\mathbf{2 0 1 5 - 1 6}$ \\
\hline $\mathrm{T}_{1}: 100 \%$ NPK & 394.44 & 397.75 & 2.47 & 2.45 \\
\hline $\mathrm{T}_{2}: 50 \mathrm{~kg}$ FYM & 426.94 & 430.00 & 2.48 & 2.47 \\
\hline $\mathrm{T}_{3}: 50 \mathrm{~kg}$ FYM+ 100\% NPK & 322.44 & 325.50 & 2.40 & 2.39 \\
\hline $\mathrm{T}_{4}: 50 \mathrm{~kg}$ FYM+ 75\% NPK & 341.69 & 344.75 & 2.44 & 2.41 \\
\hline $\mathrm{T}_{5}: 50 \mathrm{~kg}$ FYM+ 50\% NPK & 366.94 & 370.00 & 2.45 & 2.44 \\
\hline $\mathrm{T}_{6}: 50 \mathrm{~kg}$ FYM+ 200g each (Azotobacter+PSB) & 345.94 & 349.00 & 2.44 & 2.42 \\
\hline $\mathrm{T}_{7}: 50 \mathrm{~kg}$ FYM+ 100\% NPK+200g each (Azotobacter+PSB) & 303.44 & 306.50 & 2.37 & 2.34 \\
\hline $\mathrm{T}_{8}: 50 \mathrm{~kg}$ FYM+ 75\% NPK+200g each (Azotobacter+PSB) & 315.69 & 318.75 & 2.40 & 2.36 \\
\hline $\mathrm{T}_{9}: 50 \mathrm{~kg}$ FYM+ 50\% NPK+200g each (Azotobacter+PSB) & 335.19 & 338.25 & 2.42 & 2.41 \\
\hline S. Em \pm & $\mathbf{6 . 0 3}$ & $\mathbf{1 8 . 0 9}$ & $\mathbf{0 . 0 2}$ & $\mathbf{0 . 0 2}$ \\
\hline CD at 5\% & $\mathbf{1 7 . 6 1}$ & $\mathbf{5 2 . 8 1}$ & $\mathbf{N S}$ & $\mathbf{N S}$ \\
\hline
\end{tabular}


Table.5 Showing the effect of INM on chemical characters of Bael cv. NB-9

\begin{tabular}{|c|c|c|c|c|c|c|c|c|}
\hline \multirow[t]{2}{*}{ Treatment } & \multicolumn{2}{|c|}{$\begin{array}{l}\text { Total Soluble } \\
\text { Solids ( }{ }^{0} \text { Brix) }\end{array}$} & \multicolumn{2}{|c|}{$\begin{array}{l}\text { Ascorbic acid } \\
\text { (mg/ 100gpulp) }\end{array}$} & \multicolumn{2}{|c|}{ Acidity (\%) } & \multicolumn{2}{|c|}{ Tannin (\%) } \\
\hline & 2014-15 & 2015-16 & 2014-15 & 2015-16 & 2014-15 & 2015-16 & 2014-15 & 2015-16 \\
\hline $\mathrm{T}_{1}: 100 \% \mathrm{NPK}$ & 23.61 & 31.92 & 16.38 & 16.68 & 0.43 & 0.41 & 5.15 & 5.04 \\
\hline $\mathrm{T}_{2}: 50 \mathrm{~kg} \mathrm{FYM}$ & 22.96 & 30.03 & 15.53 & 16.03 & 0.46 & 0.44 & 5.29 & 5.16 \\
\hline $\mathrm{T}_{3}: 50 \mathrm{~kg} \mathrm{FYM}+100 \% \mathrm{NPK}$ & 32.01 & 33.65 & 18.52 & 18.72 & 0.34 & 0.32 & 4.45 & 4.34 \\
\hline $\mathrm{T}_{4}: 50 \mathrm{~kg} \mathrm{FYM}+75 \% \mathrm{NPK}$ & 28.60 & 33.01 & 17.24 & 17.64 & 0.37 & 0.35 & 4.90 & 4.78 \\
\hline $\mathrm{T}_{5}: 50 \mathrm{~kg} \mathrm{FYM}+50 \% \mathrm{NPK}$ & 26.19 & 32.15 & 16.11 & 16.71 & 0.41 & 0.39 & 5.08 & 4.97 \\
\hline $\mathrm{T}_{6}: 50 \mathrm{~kg} \mathrm{FYM}+200 \mathrm{~g}$ each (Azotobacter+PSB) & 27.49 & 32.95 & 17.26 & 17.56 & 0.38 & 0.35 & 4.96 & 4.82 \\
\hline $\mathrm{T}_{7}: 50 \mathrm{~kg} \mathrm{FYM}+100 \% \mathrm{NPK}+200 \mathrm{~g}$ each $($ Azotobacter+PSB $)$ & 35.66 & 37.86 & 20.75 & 21.26 & 0.30 & 0.28 & 4.28 & 4.00 \\
\hline $\mathrm{T}_{8}: 50 \mathrm{~kg} \mathrm{FYM}+75 \% \mathrm{NPK}+200 \mathrm{~g}$ each $($ Azotobacter+PSB $)$ & 33.48 & 35.25 & 18.40 & 18.80 & 0.31 & 0.29 & 4.37 & 4.12 \\
\hline $\mathrm{T}_{9}: 50 \mathrm{~kg}$ FYM+ 50\% NPK+200g each (Azotobacter+PSB) & 28.78 & 33.31 & 17.89 & 18.19 & 0.36 & 0.34 & 4.68 & 4.58 \\
\hline S. Em \pm & 0.95 & 1.15 & 0.12 & 0.06 & 0.012 & 0.11 & 0.15 & 0.15 \\
\hline CD at $5 \%$ & 2.79 & 3.38 & 0.35 & 0.20 & 0.036 & 0.034 & 0.45 & 0.44 \\
\hline
\end{tabular}

Table.6 Showing the effect of INM on chemical characters of Bael cv. NB-9

\begin{tabular}{|c|c|c|c|c|c|c|c|c|}
\hline \multirow[t]{2}{*}{ Treatment } & \multicolumn{2}{|c|}{$\begin{array}{c}\text { Reducing sugars } \\
(\%)\end{array}$} & \multicolumn{2}{|c|}{$\begin{array}{l}\text { Non-reducing } \\
\text { sugar }(\%)\end{array}$} & \multicolumn{2}{|c|}{ Total sugars (\%) } & \multicolumn{2}{|c|}{$\begin{array}{l}\text { Total carotene } \\
\text { ( } \mu \mathrm{g} / \mathbf{1 0 0 g} \text { pulp) }\end{array}$} \\
\hline & 2014-15 & $2015-16$ & 2014-15 & 2015-16 & 2014-15 & 2015-16 & 2014-15 & $2015-16$ \\
\hline $\mathrm{T}_{1}: 100 \% \mathrm{NPK}$ & 4.93 & 5.18 & 8.19 & 8.33 & 13.12 & 13.52 & 52.41 & 52.45 \\
\hline $\mathrm{T}_{2}: 50 \mathrm{~kg} \mathrm{FYM}$ & 4.78 & 4.98 & 7.81 & 7.99 & 12.59 & 12.97 & 52.02 & 52.15 \\
\hline $\mathrm{T}_{3}: 50 \mathrm{~kg}$ FYM+ $100 \% \mathrm{NPK}$ & 5.71 & 5.99 & 9.20 & 9.49 & 14.90 & 15.48 & 54.09 & 54.45 \\
\hline $\mathrm{T}_{4}: 50 \mathrm{~kg} \mathrm{FYM}+75 \% \mathrm{NPK}$ & 5.48 & 5.72 & 8.89 & 9.04 & 14.35 & 14.76 & 53.23 & 53.55 \\
\hline $\mathrm{T}_{5}: 50 \mathrm{~kg} \mathrm{FYM}+50 \% \mathrm{NPK}$ & 5.10 & 5.40 & 8.31 & 8.46 & 13.41 & 13.85 & 52.88 & 52.90 \\
\hline $\mathrm{T}_{6}: 50 \mathrm{~kg}$ FYM+ 200g each (Azotobacter+PSB) & 5.27 & 5.55 & 8.29 & 8.53 & 13.55 & 14.08 & 53.01 & 53.12 \\
\hline $\mathrm{T}_{7}: 50 \mathrm{~kg}$ FYM+ $100 \% \mathrm{NPK}+200 \mathrm{~g}$ each (Azotobacter+PSB) & 6.34 & 6.58 & 9.47 & 9.61 & 15.81 & 16.19 & 55.72 & 55.84 \\
\hline $\mathrm{T}_{8}: 50 \mathrm{~kg}$ FYM+ 75\% NPK+200g each (Azotobacter+PSB) & 6.14 & 6.38 & 9.34 & 9.52 & 15.47 & 15.90 & 54.83 & 54.85 \\
\hline $\mathrm{T}_{9}: 50 \mathrm{~kg}$ FYM+ 50\% NPK+200g each (Azotobacter+PSB) & 5.76 & 5.92 & 9.07 & 9.28 & 14.82 & 15.19 & 53.78 & 54.18 \\
\hline S. Em \pm & 0.10 & 0.11 & 0.24 & 0.24 & 0.29 & 0.29 & 0.10 & 0.07 \\
\hline CD at $5 \%$ & 0.31 & 0.34 & 0.72 & 0.72 & 0.85 & 0.86 & 0.30 & 0.22 \\
\hline
\end{tabular}


The data in respect to reducing sugars, nonreducing sugar and total sugars is presented in table 6 shows that the soil application of the treatment T7-50 Kg FYM + 100\% NPK + 200g each (Azotobacter + PSB) increased the level of sugars in the bael fruit than all others treatments during both the years of experimentation (2014-15 and 2015-16). While the treatment T8-50 Kg FYM + 75\% $\mathrm{NPK}+200 \mathrm{~g}$ each (Azotobacter $+\mathrm{PSB})$ and T3-50 Kg FYM + 100\% NPK were found at par followed by $\mathrm{T} 9-50 \mathrm{~kg} \mathrm{FYM}+50 \%$ $\mathrm{NPK}+200 \mathrm{~g}$ each (Azotobacter $+\mathrm{PSB})$. The application of the treatment T2-50kg FYM was recorded lowest results in comparison to all other treatments.

Results indicated that T7-50 Kg FYM + 100\% $\mathrm{NPK}+200 \mathrm{~g}$ each (Azotobacter + PSB) gave better response to improving fruit quality of bael fruit. The improvement in fruit quality with the application of NPK and FYM in present investigation was might be due to increased continuous supply of nutrients, higher concentration of soil enzymes, soil microorganism, rapid mineralization and transformation of plant nutrients in soil and also growth promoting substances produced by microorganism. Singh et al., (2013), Srivastava and Mishra (2013), Ram et al., (2012), Baviskar et al., (2011), Dutta et al.(2003) and Singh et al., (2008) reported that accumulation of TSS, ascorbic acid, total sugar and reduction in fruit acidity was found with the increased dose of bio-fertilizers were integrated with organic and inorganic manures. The results also corroborate with the findings of Mishra et al., (2011), they observed an improvement in total soluble solids and reducing sugar contents in ber cv. Gola with different graded levels of FYM (37.5, 75 and $150 \mathrm{~kg} / \mathrm{plant}$ ) and Vermicompost (11, 22 and $45 \mathrm{~kg} /$ plant). The results of Yadav et al., (2011) also support the findings working on papaya fruit. They reported better fruit quality in papaya plant with the application of $10 \quad \mathrm{~kg}$ Vermicompost+100\% NPK+25 g Azotobacter possess fairly better fruit qualities.

It is evident from the data presented table 5 shows that the fruit acidity and tannin percent of bael fruit were significantly reduced in all treatments with use of FYM+ NPK with biofertilizers (Azotobacter and PSB), while best results in respect to fruit acidity $(0.30 \%$ and $0.28 \%)$ and tannin per cent $(4.28 \%$ and $4.00 \%$ ) were recorded with the soil application of T7-50 Kg FYM + 100\% NPK + $200 \mathrm{~g}$ each (Azotobacter + PSB). The application of T8 $-50 \mathrm{Kg} \mathrm{FYM} \mathrm{+} \mathrm{75 \%} \mathrm{NPK} \mathrm{+}$ $200 \mathrm{~g}$ each (Azotobacter + PSB) was found at par $(0.31 \%$ and $0.29 \%)$ followed by $\mathrm{T} 3-50 \mathrm{Kg}$ FYM $+100 \%$ NPK during both the years (2014-15 and 2015-16) of experimentation.

This might be due to the better nitrogen fixation under Azotobacter applied treatment increased the absorption of nitrogen and PSB treatment greater solubilization of insoluble phosphorus along with some other factors like release of growth promoting substances, control of plant pathogen and proliferation of beneficial organisms in rhizosphere, plant supplied with sufficient $\mathrm{N}$ and $\mathrm{P}$ continuously maintained vegetative growth leading to increase in photosynthetic area which in turn resulted in more accumulation of assimilates of partitioning to the matured berries in strawberry. The findings of this experiment are similar to the results reported Tripathi et al., (2010), Singh et al., (2008), EI-Hamid et al., (2006), Rana and Chandel (2003) in strawberry. Results are in line with the findings of Duttaet al., (2003), that $100 \% \mathrm{~N}+$ $100 \% \mathrm{P}+$ Bio-fertilizers was best treatment with respect to quality parameters in sweet orange. Yadav (2006) reported that application of Vermicompost with $100 \%$ NPK recorded maximum TSS, Total sugar and reduction in acidity of papaya fruit. Results of the present investigation are also in 
conformity with the findings of Athani et al., (2009). They noticed highest TSS, total sugar and ascorbic acid in guava cv. Sardar guava with the application of $75 \%$ NPK + Vermicompost over the $100 \%$ NPK.

\section{Acknowledgement}

The author is grateful to the Advisor, Head, and all the members of advisory committee, Department of Horticulture, Narendra Deva University of Agriculture and Technology, Kumarganj, Faizabad, for providing necessary facilities.

\section{References}

Aariff Khan, M.A.; Begum, H. and Swarajyalakshmi, G. (2004). Influence of components of integrated nutrient management on fruit yield and quality of acid lime in red calcareous soil. Annals of Agri. Res.; 25(1):124-128.

Athani, S.I.; Ustad, A.I.; Praburaj, H.S.; Swamy, G.S.K.; Patil, P.B. and Katikal, Y.K. (2009). Influence of vermicompost on growth, fruit yield and quality of guava cv. Sardar. Acta Hort., 1: 735.

Atiyeh, R.M.; Edward, C.A.; Subler, S. and Metzger, J.D. (2001). Pig manure vermicompost as a component of a horticulture bedding plant medium: effects on physiochemical properties and plant growth. Bio. Tech., 75: 11-20.

Baviskar, M. N.; Bharad, S. G.; Dod, V. N. and Barne, V.G. (2011).Effect of integrated nutrient management on yield and quality of sapota. Plant Arch.; 11(2):661-663.

Bendegumbal, S.; Sajjan, Ashok, S.; Vyakaranahal, B.S.; Malbasari, T.A.; Hosamani, R.M. and Patil, A.B. (2008). Studies of organic seed production in onion. Karnataka J. Agric. Sci., 21(1): 120-121.
Dutta, P.; Chakroborty, A.K. and Chakroborty, P.K. (2003).Effects of different levels of NPK and biofertilizer on fruit quality and yield of sweet orange. Ann. Agric. Res., 24(4): 786-788.

EI-Hamid, A.S.; Aza, A.A.A.; Mansour, S.A.A. and EI.Sayed, A.A.A. (2006).Effect of some bio-fertilizers on the yield, and fruit quality of strawberry. Annals of Agri. Sci.; Moshtohor, 44(10): 251-264.

Ghosh, S. N.; Bera, B.; Roy, S. and Kundu, A. (2012). Integrated nutrient management in pomegranate grown in laterite soil. Indian J. of Hort.; 69(3):333-337.

Govindan, M. and Purushothaman, D. (1984).Production of phyto-hormones by the nitrogen fixing bacterium Azospirillum. Agri. Res. J. Kerala, 22(2): 133-138.

Kumar, V.; Singh, M. K.; Singh, M.; Dev, P. and Mohan, B. (2012). Influence of integrated nutrient management (INM) on yield and quality of lemon (Citrus limon Burn.) cv. pant lemon-I under western U.P. conditions. Annals of Hort.; 5(1):137-139.

Mani, S.; Meena, M. L.; Kumar, V. and Ram, R. B. (2013).Impact of INM on growth and yield of phalsa (Grewia subinaequalis D.C.).Envir.and Eco.; 31(2B):898-903.

Manjunath, H.; Ganigar, V. M.; Reddy, B.G. and Joshi, V.R. (2006).Integrated nutrient management in sapota (Achorussapota) using vermicompost to increase yield and quality. Indian $\mathrm{J}$. Agric. Sci., 76(10): 587-590.

Mishra, S.; Choudhary, M. R.; Yadav, B. L. and Singh, S. P. (2011).Studies on the response of integrated nutrient management on growth and yield of ber.Ind. J. of Hort.; 68(3):318-321. 
Nambiar, K.K.M. and Abrol, I.P. (1989). Long term fertilizer experiment in India: An overview. Fertilizer News, 34(4): 11-26.

Ram, R. B.; Kuldeep; Meena, M. L.; Lata, R. and Bharti, N. (2012).Integrated nutrient management studies for some quality characters of phalsa. Asian J. of Hort.; 7(2):385-387.

Rana, R. K. and Chandel, S. (2003).Effect of bio-fertilizer and nitrogen on growth, yield and fruit quality of strawberry. Prog. Hort., 35(1): 23-30.

Singh, A.; Yadav, A. L.; Yadav, D. K.; Misra, S. K. (2008). Effect of integrated nutrient management of yield and quality of aonla (Emblica officinalis Gaertn.) cv. NA-10.Plant Archives; 8(1):473-474.

Singh, S. R.; Sharma, M. K.; Sharma, V. K.; Srivastava, K. K. and Sundouri, A. S. (2013). Integrated management of phosphorus in high density apple cv. Red Delicious under temperate condition of Kashmir. Prog. Hort.; 45(1):69-75.
Srivastava, D. and Misra, K. K. (2013).Effect of phosphorous on growth and nutrient status of Bael (Aegle marmelosCorrea) under sand culture. PantNagar J. of Res.; 11(1):65-69.

Tripathi, V.K.; Kumar, N.; Shukla, H.S. and Mishra, A.N. (2010). Influence of Azotobacter, Azospirillum and PSB on growth, yield and quality of strawberry cv. Chandler, paper presented in National Symposium on Conservation Hort., during March, 21-23, 2010 at Dehradunn, pp 198-199.

Yadav, P. K.; Yadav, A. L.; Yadav, A. S. and Yadav, H. C. (2011). Effect of integrated nutrient nourishment on vegetative growth and physico-chemical attributes of papaya (Carica papaya Linn.) fruit cv.pusa dwarf. Plant Archives; 11(1):327-329.

Yadav, P.K. (2006).Effect of integrated nutrient management on growth, yield and quality of papaya (Carica papaya L.) fruit. Ph.D. Thesis, C.S.A.U. \& T., Kanpur (U.P.).

\section{How to cite this article:}

Govind Vishwakarma, A. L. Yadav, Amit Kumar, Amar Singh and Sonu Kumar. 2017. Effect of Integrated Nutrient Management on Physico-Chemical Charactersof Bael (Aegle marmelos Correa) cv. Narendra Bael-9. Int.J.Curr.Microbiol.App.Sci. 6(6): 287-296. doi: https://doi.org/10.20546/ijcmas.2017.606.035 